\title{
ANALISIS PENGARUH HARGA BAHAN BAKAR MINYAK (BBM) PERTAMINA DAN STRATEGI PENGADAAN STOK TERHADAP PENDAPATAN PERUSAHAAN DI SPBU PT. MA'SOEM BANDUNG
}

\author{
Ernie Mardiany Dj \\ Fakultas Ekonomi dan Bisnis \\ Universitas Islam Syekh Yusuf Tangerang \\ erniemardianydj@gmail.com \\ https://doi.org/10.33592/jeb.v25i2.424
}

\begin{abstract}
Abstrak
Harga bahan bakar minyak (BBM) di Indonesia yang dikelola oleh Pertamina sering dalam kondisi tidak dapat memastikan kestabilan harga, yang tentunya berimbas kepada SPBU sebagai retail yang menjual langsung kepada masyarakat.Dengan kondisi ini SPBU tetap harus melayani masyarakat, menjual BBM-nya sesuai stok dengan harga pembelian yang sudah ditentukan saat penyerahan dari Pertamina. Penelitian ini bertujuan menganalisis pengaruh harga BBMdan strategi yang dilakukan oleh SPBU dalam pengadaan BBM terhadap pendapatan perusahaan. Penelitian ini merupakan penelitian kuantitatif dengan menggunakan metode survey kausal, dan analisis regresi korelasional yang menguraikan hubungan antara variabel bebas (harga BBM Pertamina dan strategi pengadaan stok) dengan variabel terikat (pendapatan perusahaan). Teknik pengumpulan data menyebarkan angket kepada responden sebanyak 30 responden. Hasil penelitian menunjukan bahwa : (1). Terdapat pengaruh yang positif dan signifikan antara harga BBM Pertamina terhadap pendapatan perusahaan, (2). Terdapat pengaruh yang positif dan signifikan antara strategi pengadaan stok terhadap pendapatan perusahaan, (3). Terdapat pengaruh yang positif dan signifikan secara simultan antara harga BBM Pertamina dan strategi pengadaan stok terhadap pendapatan perusahaan. Kesimpulan penelitian terdapat pengaruh yang positif dan signifikan secara simultan antara harga BBM Pertamina dan strategi pengadaan stok terhadap pendapatan perusahaan. Dengan ditunjukkan dari hasil uji $\mathrm{F}$ hitung sebesar 11,23 lebih besar dibandingkan $\mathrm{F}$ tabel sebesar 3.35 dengan taraf signifikan 5\% dan $\mathrm{dk}=27$.

Kata kunci : Strategi Pengadaan Stok, Harga BBM, dan Pendapatan Perusahaan
\end{abstract}




\begin{abstract}
The price of fuel (BBM) in Indonesia run by Pertamina, often in conditions cannot ensure price stability, which certainly imposes to GAS STATIONS as retail who sell directly to the public. With this condition GAS STATIONS still need to serve the community, selling his stock to FUEL in accordance with the purchase price already determined at the moment of submission of Pertamina.This research aims to analyze the effect of fuel prices and the strategies undertaken by the GAS STATION FUEL procurement against corporate earnings. This research is a quantitative research survey using causal, and regression analysis correlation method that illustrate the relationship between independent variable that is Pertamina fuel price and stock procurement strategy with revenues as dependent variable revenues. Techniques in collecting data by distributing questionnaires to the 30 respondents. The results showed that first, there is a positive and significant influence of the price fuel oil Pertamina to company's revenues, the second there is a positive and significant influenceof the stock procurement strategy to the company's revenues, and third there are simultaneous positive and significant influence between the price of fuel oil Pertamina's and stock procurement strategy to the company's revenue.The conclusion of this study is that there is simultaneous positive and significant influence between Pertamina's fuel price and the stock procurement strategy to the company's revenue. This is shown by the test $F$ results by 11.23 larger than $F$ table at 3.35 with a significant level of $5 \%$ and $d k=27$.
\end{abstract}

Keywords : Price of fuel oil (BBM), Fuel stock procurement strategy, and corporate revenue

\section{PENDAHULUAN}

$\begin{array}{ccr} & \text { Pendapatan merupakan } & \text { sesuatu } \\ \text { yang sangat penting dalam } & \text { setiap } \\ \text { perusahaan, dan } & \text { sangat } \\ \text { berpengaruh bagi kelangsungan } & \text { hidup }\end{array}$
perusahaan.Semakin besar pendapatan yang diperoleh perusahaan maka semakin besar pula kemampuan perusahaan untuk membiayai segala pengeluaran dan kegiatan-kegiatan yang akan dilakukan oleh perusahaan. Salah satu sumber pendapatan bagi perusahaan adalah pendapatan dari transaksi-transaksi penjualan produk yang dimilikinya. Dalam transaksi penjualan produknya, perusahaan dituntut untuk menentukan harga produk yang akan di jual kepada konsumen, penentuan harga dalam perusahaan merupakan titik kritis, karena harga sebagai penentu pendapatan bagi perusahaan itu sendiri. Dan juga keputusan penentuan harga harus mampu mencerminkan seluruh kepentingan perusahaan, dengan memahami faktor-faktor yang secara langsung akan mempengaruhi tingkat harga yang akan ditentukan.

Kegiatan penting perusahaan lainnya dalam menjalankan roda bisnisnya adalah kegiatan atau aktivitas pengadaan dengan melalui suatu proses menjadikan sesuatu yang tadinya tidak ada menjadi ada. Pengadaan barang yang sehari-hari disebut juga sebagai kegiatan atau aktivitas pembelian atau pembelanjaan merupakan titik awal dari pengendalian persediaan.

Persediaan atau disebut juga dengan stok dalam perusahaan diperlukan untuk menciptakan suatu kondisi dimana suatu barang disimpan dalam jangka waktu 
tertentu untuk memenuhi kebutuhan.Pada dasarnya persediaan dapat mempermudah dan memperlancar jalannya operasi pada perusahaan, juga merupakan salah satu komponen modal kerja. Persediaan sangat penting bagi perusahaan karena dengan adanya persediaan menjembatani kegiatan pembelian, kegiatan produksi, kegiatan penjualan, dan juga dengan adanya persediaan memperkecil kemungkinan perusahaan gagal dalam memenuhi permintaan pelanggan, atau dapat juga menjadikan proses produksi terhenti, hal ini tentu saja akan menghambat terhadap tujuan utama perusahaan yaitu mendapatkan laba sebagai salah satu pendapatan bagi perusahaan. Perusahaan dalam menjalankan fungsi pembelanjaan/pengadaan persediaan (stok) dituntut suatu cara atau pedoman sebagai strategi yang harus dilaksanakan oleh perusahaan sebagai alat untuk mencapai tujuan jangka panjang perusahaan.

Strategi merupakan kebutuhan yang vital dan sangat penting dalam menjalankan roda perusahaan menghadapi berbagai macam tantangan, baik internal maupun eksternal.Strategi diperlukan apabila perusahaan menghadapi keadaan sumber daya yang dimiliki terbatas, adanya ketidak pastian (uncertainity), komitmen (commitment) terhadap sumber daya tidak dapat dirubah lagi, keputusan-keputusan (decisions) harus dikoordinasikan antar bagian sepanjang waktu.

Keberhasilan strategi dalam pengadaan stok menjadikan titik awal dari pengendalian persediaan yang pada akhirnya dapat didistribusikan kepada konsumen dengan harga jual yang diharapkan, dan merupakan benefit yang diharapkan oleh perusahaan, sebagai pendapatan (revenue).
Sebagai sebuah perusahaan PT. Ma'soem merupakan salah satu perusahaan yang berlokasi di wilayah Bandung, merupakan perusahaan yang mengelola beberapa bidang usaha diantaranya bergerak dibidang bahan bakar minyak dengan memiliki beberapa SPBU yang tersebar di beberapa wilayah seperti di wilayah kota Bandung, Bandung Barat, Bandung Selatan, Sumedang, Cianjur, Jatiwangi, Subang, Majalengka, Purwakarta, dan Tasikmalaya. yang mengelola usaha sebagai penyalur retail bahan bakar minyak (BBM) dari PT. Pertamina, maka PT. Ma'soem terikat perjanjian dengan PT. Pertamina, salah satu point perjanjian dengan PT. Pertamina adalah dalam penetapan harga.

Penetapan harga jual Bahan Bakar Minyak dan Bahan Bakar Khusus oleh pihak pertama (Pertamina), dan pihak kedua (Pengusaha SPBU) akan diberikan margin yang besarnya ditetapkan oleh pihak pertama.

Dalam penyerahan BBM oleh Pertamina kepada pengusaha SPBU dilakukan dengan harga dan syarat-syarat penyerahan yang ditetapkan olehPertamina, yang berlaku pada tanggal/ saat penyerahan.

Harga bahan bakar minyak (BBM) di Indonesia dalam hal ini dikelola oleh Pertamina sering dalam kondisi tidak dapat memastikan kestabilan harga, yang tentunya berimbas pula kepada setiap SPBU sebagai retail yang menjual langsung kepada masyarakat sebagai konsumen.

Kondisi harga yang tidak stabil, sementara SPBU harus tetap melayani masyarakat sebagai konsumen yang memerlukan bahan bakar minyak harus tetap dilayani. Dan stok bahan bakar minyak yang dimiliki dengan harga yang sudah ditentukan atau yang berlaku saat 
penyerahan bahan bakar minyak sebelumnya. Dengan kondisi tersebut, menuntut perusahaan SPBU khususnya dalam hal ini SPBU PT. Ma'soem untuk melakukan pendekatan secara keseluruhan yang berkaitan dengan strategi sebagai pendoman untuk merencanakan bagaimana melakukan pengadaan persediaan (stok) bahan bakar minyak dengan harga yang telah tentukan oleh pihak pertama yaitu Pertamina.

Berdasarkan uraian di atas membuat penulis tertarik untuk mengetahui dan menganalisis secara lebih mendalam apakah harga bahan bakar minyak (BBM) dan juga strategi yang dilakukan perusahaan dalam pengadaaan persediaan (stok) bahan bakar minyak (BBM) mempengaruhi terhadap pendapatan perusahaan. Berlandaskan latar belakang masalah, maka dirumuskan permasalahan penelitian sebagai berikut : Pertama apakah terdapat pengaruh antara harga Bahan Bakar Minyak (BBM) Pertamina terhadap pendapatan perusahaan di SPBU PT. Ma'soem Bandung ?; Kedua apakah terdapat pengaruh antara strategi pengadaan stok terhadap pendapatan perusahaan di SPBU PT. Ma'soem Bandung ?; Ketiga apakah terdapat pengaruh secara simultan antara harga Bahan Bakar Minyak (BBM) Pertamina dan strategi pengadaan stok terhadap pendapatan perusahaan di PT. Ma'soem Bandung?.

Adapun tujuan yang ingin dicapai dalam penelitian, yaitu sebagai berkitu : Pertama untuk mengetahui pengaruh harga Bahan Bakar Minyak (BBM) Pertamina terhadap pendapatan perusahaan di SPBU PT. Ma'soem Bandung; Kedua untuk mengetahui pengaruh strategi pengadaan stok terhadap pendapatan perusahaan di
SPBU PT. Ma'soem Bandung; Ketiga untuk mengetahui pengaruh harga Bahan Bakar Minyak (BBM) Pertamina dan strategi pengadaan stok terhadap pendapatan perusahaan di SPBU PT. Ma'soem Bandung.

Secara garis besar hasil penelitian ini dapat bermanfaat untuk meningkatkan pendapatan perusahaan di SPBU PT. Ma'soem Bandung, melalui kebijakan harga dan melalui strategi dalam pengadaan stok.

\section{METODOLOGI PENELITIAN}

\section{Metode Penelitian}

Penelitian ini merupakan penelitian kuantitatif dengan menggunakan metode survey kausal.Tingkat eksplanasi dalam metode penelitian ini adalah penelitian asosiatif.Variabel dalam penelitian ini meliputi dua variabel bebas yaitu variable harga $\left(\mathrm{X}_{1}\right)$ dan variable staregi pengadaan stok $\left(\mathrm{X}_{2}\right) \quad$ serta satu variabel terikat yaitu pendapatan perusahaan $(\mathrm{Y})$.

Model hipotetik dalam penelitian ini adalah sebagai berikut :

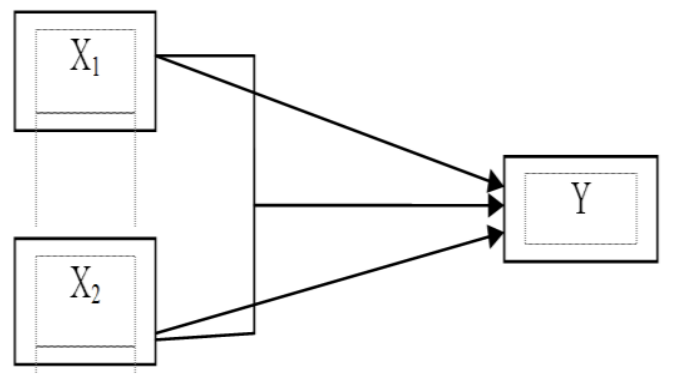

Gambar : Model Hipotetik

Keterangan Gambar : $\quad \mathrm{X}_{1}=$ Harga $\quad \mathrm{X}_{2}=$ Strategi

Pengadaan Stok $\quad \mathrm{Y}=$ Pendapatan Perusahaan 


\section{Ekonomi Bisnis \\ JEB \\ Volume 25, Nomor 2, Januari 2020 \\ P-ISSN: 1411 - 545X | E ISSN: 2715-1662}

Data penelitian diperoleh dengan menyebarkan angket ke 30 (tiga puluh) SPBU milik PT. Al. Ma'soem yang tersebar dibeberapa lokasi.

\section{Teknik Analisis Data}

a. Korelasi Sederhana, digunakan untuk menemukan (meneliti) ada atau tidaknya hubungan antara variabel harga $\left(\mathrm{X}_{1}\right)$ sebagai variabel bebas pertama dengan variabel pendapatan perusahaan $(\mathrm{Y})$ sebagai variabel terikat, dan variabel strategi pengadaan stok $\left(\mathrm{X}_{2}\right)$ sebagai variabel bebas kedua dengan variabel Pandapatan Perusahaan (Y) sebagai variabel terikat. Tinggi rendahnya tingkat keeratan hubungan antar variabel dalam penelitian dapat dilihat dari besar kecilnya nilai koefisien (r) yang diperoleh dari hasil analisis data.Rumus yang digunakan untuk menganalisis koefisien korelasi adalah Pearson Product Moment.

b. Analisis Regresi Linier Berganda, dengan persamaan regresi sebagai berikut :

$\mathrm{Y}=\mathrm{a}+\mathrm{b}_{1} \mathrm{X}_{1}+\mathrm{b}_{2} \mathrm{X}_{2}$

c. Uji T, untuk menguji signifikansi hubungan antara masing-masing variable.

d. Koefisien Determinasi, untuk mengukur berapa besarnya pengaruh harga dan strategi pengadaan stok terhadap pendapatan perusahaan.

e. Uji F, digunakan untuk menguji ada tidaknya hubungan antara harga, dan strategi pengadaan stok dengan pendapatan perusahaansecara simultan.

f. Uji Hipotesis Statistik, untuk menguji apakah nilai parameter betul-betul ada atau tidak ada.

\section{HASIL PENELITIAN dan PEMBAHASAN}

Berdasarkan hasil pengujian dan analisis data dapat diuarikan sebagai berikut :

\section{a. Uji Normalisasi Data (dengan teknik Kolmogorov-Smirnov) \\ Pengujian normalisasi data harga BBM Pertamina}

Berdasarkan hasil perhitungan ditemukan bahwa harga Dohitung $=0,0561$ sedangkan $\mathrm{D}$ tabeldengan taraf signifikan $(\alpha) 5 \%$ dan $\mathrm{n}=30, \mathrm{D}(0,05 ; 30)$ adalah 0,242 . Karena harga Do hitung lebih kecil dari harga Do tabel $(0,0561<0,242)$, maka uji D tidak jatuh di daerah kritis (daerah penolakan $\mathrm{H}_{0}$ ), jadi $\mathrm{H}_{0}$ diterima. Dapat disimpulkan bahwa data harga Bahan Bakar Minyak (BBM) untuk $\mathrm{X}_{1}$ berdistribusi normal

Pengujian normalisasi data strategi pengadaan stok

Berdasarkan hasil perhitungan ditemukan bahwa harga Dohitung $=0,1719$ sedangkan D tabeldengan taraf signifikan $(\alpha) 5 \%$ dan $\mathrm{n}$ $=30, \mathrm{D}(0,05 ; 30)$ adalah 0,242. Karena harga Do hitung lebih kecil dari harga Do tabel $(0,1719<0,242)$, maka uji $\mathrm{D}$ tidak jatuh di daerah kritis (daerah penolakan $\mathrm{H}_{0}$ ), jadi $\mathrm{H}_{0}$ diterima. Dapat disimpulkan bahwa data strategi pengadaan stok $\left(\mathrm{X}_{2}\right)$ berdistribusi normal.

\section{Pengujian data pendapatan perusahaan}

Berdasarkan hasil perhitungan ditemukan bahwa harga Dohitung $=0,2026$ sedangkan D tabeldengan taraf signifikan $(\alpha) 5 \%$ dan $n$ $=30, \mathrm{D}(0,05 ; 30)$ adalah 0,242 . Karena harga Do hitung lebih kecil dari harga Do tabel $(0,2026<0,242)$, maka uji D tidak jatuh di daerah kritis (daerah penolakan $\mathrm{H}_{0}$ ), jadi $\mathrm{H}_{0}$ diterima. Dapat disimpulkan bahwa data pendapatan perusahaan (Y) berdistribusi normal.

\section{b. Analisis Regresi Linier Sederhana dan Berganda}


Rangkuman Hasil Uji Regresi Linier Sederhana

\begin{tabular}{|c|c|c|c|c|}
\hline \multirow{2}{*}{ VARIABEL } & \multicolumn{2}{|c|}{ KONSTANTA } & \multirow{2}{*}{$\begin{array}{c}\text { PERSAMAAN } \\
\text { REGRESI }\end{array}$} & \multirow{2}{*}{ KET } \\
\hline & $\mathbf{a}$ & b & & \\
\hline $\mathrm{X}_{1}$ terhadap Y & 53,2557 & 0,1849 & $Y=53,2557+0,1849 \mathrm{X} 1$ & $\begin{array}{lrr}\text { Persamaan regresi yang } & \text { yan } \\
\text { digunakan untuk memprediksi } \\
\text { pendapatan perusahaan } \\
\text { berdasarkan harga Bahan } \\
\text { Bakar Minyak Pertamina }\end{array}$ \\
\hline $\mathrm{X}_{2}$ terhadap $\mathrm{Y}$ & 28,3617 & 0,6236 & $Y=28,3617+0,6236 \mathrm{X} 2$ & $\begin{array}{lrr}\text { Persamaan regresi } & \text { yang } \\
\text { digunakan untuk } & \text { memprediksi } \\
\text { pendapatan } & \text { perusahaan } \\
\text { berdasarkan } & \text { strategi } \\
\text { pengadaan stok } & \end{array}$ \\
\hline
\end{tabular}

Rangkuman Hasil Uji Regresi Linier Berganda

\begin{tabular}{|l|c|c|c|c|c|}
\hline \multirow{2}{*}{ VARIABEL } & \multicolumn{2}{|c|}{ KONSTANTA } & \multicolumn{2}{c|}{ PERSAMAAN } & \multicolumn{1}{c|}{ KET } \\
\cline { 2 - 4 } & $\mathbf{a}$ & $\mathbf{b}_{\mathbf{1}}$ & $\mathbf{b}_{\mathbf{2}}$ & \multirow{2}{*}{ REGRESI } & $\begin{array}{l}\text { Persamaan regresi yang } \\
\text { digunakan untuk mem- } \\
\text { prediksi pendapatan pe- } \\
\text { rusahaan berdasarkan } \\
\text { harga BBM Pertamina } \\
\text { dan strategi pengadaan } \\
\text { stok }\end{array}$ \\
\hline $\begin{array}{l}\text { Harga BBM } \\
\begin{array}{l}\text { Pertamina dan } \\
\text { Strategi Penga } \\
\text { daan Stok } \\
\text { terhadap Pen- } \\
\text { dapatan Peru- } \\
\text { sahaan }\end{array}\end{array}$ & 25,4761 & 0,1190 & 0,5429 & $\mathrm{Y}=25,4761+0,1190 \mathrm{X}_{1}+0,5429 \mathrm{X}_{2}$ \\
\hline
\end{tabular}

\section{c. Korelasi Sederhana}

Rangkuman Hasil Uji Korelasi (r) Pearson Product Moment

\begin{tabular}{|c|l|c|}
\hline NO & \multicolumn{1}{|c|}{ VARIABEL YANG DIKORELASIKAN } & r \\
\hline 1 & $\begin{array}{l}\text { Variabel Harga Bahan Bakar Minyak Pertamina }\left(\mathrm{X}_{1}\right) \text { dengan Pendapatan } \\
\text { Perusahaan }(\mathrm{Y})\end{array}$ & 0,4335 \\
\hline 2 & $\begin{array}{l}\text { Variabel Strategi Pengadaan Stok }\left(\mathrm{X}_{2}\right) \text { dengan Pendapatan Perusahaan } \\
(\mathrm{Y})\end{array}$ & 0,6185 \\
\hline 3 & $\begin{array}{l}\text { Variabel Harga Bahan Bakar Minyak Pertamina }\left(\mathrm{X}_{1}\right) \text { dan Strategi } \\
\text { Pengadaan Stok }\left(\mathrm{X}_{2}\right) \text { dengan Pendapatan Perusahaan }(\mathrm{Y})\end{array}$ & 0,6738 \\
\hline
\end{tabular}

\section{d. Koefisien Determinasi}

\begin{tabular}{|c|l|c|}
\multicolumn{3}{|c|}{ Rangkuman Hasil Perhitungan Koefisien Determinasi } \\
\hline NO & \multicolumn{1}{|c|}{ VARIABEL } & KD \\
\hline 1 & $\begin{array}{l}\text { Harga Bahan Bakar Minyak Pertamina }\left(\mathrm{X}_{1}\right) \text { dan Pendapatan } \\
\text { Perusahaan }(\mathrm{Y})\end{array}$ & $18,7922 \%$ \\
\hline 2 & Strategi Pengadaan Stok $\left(\mathrm{X}_{2}\right)$ dan Pendapatan Perusahaan $(\mathrm{Y})$ & $38,2542 \%$ \\
\hline 3 & $\begin{array}{l}\text { Harga Bahan Bakar Minyak Pertamina }\left(\mathrm{X}_{1}\right) \text { dan Strategi Pengadaan } \\
\text { Stok }\left(\mathrm{X}_{2}\right) \text { dengan Pendapatan Perusahaan }(\mathrm{Y})\end{array}$ & $45,4006 \%$ \\
\hline
\end{tabular}

\section{e. Uji Hipotesis}

(1). Uji Signifikansi Parsial ( Uji T ) 
Uji Signifikansi Variabel Harga BBM Pertamina $\left(X_{1}\right)$ dengan Variabel Pendapatan Perusahaan (Y)

Hipotesis penelitian yang akan di uji dirumuskan sebagai berikut :

$\mathrm{H}_{0}$ : Tidak terdapat pengaruh antara harga BBM Pertamina terhadap pendapatan perusahaan di SPBU PT. Ma'soem Bandung.

$\mathrm{H}_{1}$ : Terdapat pengaruh antara harga BBM Pertamina terhadap pendapatan perusahaan di SPBU PT. Ma'some Bandung.

Berdasarkan hasil perhitungan dengan uji $\mathrm{t}$ diperoleh $\mathrm{t}$ hitung sebesar 2,5455 dengan taraf signifikan $0,025(0,05: 2)$ dan dengan $\mathrm{db}=28$ diperoleh nilai $\mathrm{t}$ tabel sebesar 2,048. Dari hasil perhitungan maka diketahui bahwa t hitung $=2,5455>$ $\mathrm{t}$ tabel $=2,048$ maka $\mathrm{H}_{0}$ ditolak dan $\mathrm{H}_{1}$ diterima. Dengan demikian dapat disimpulkan bahwa terdapat pengaruh yang signifikan antara harga BBM Pertamina dengan pendapatan perusahaan di SPBU PT. Ma'soem Bandung.

Uji Signifikansi Variabel Strategi Pengadaan Stok $\left(\mathrm{X}_{2}\right)$ dengan Variabel Pendapatan Perusahaan (Y)

Hipotesis yang akan di uji dirumuskan sebagai berikut :

$\mathrm{H}_{0}$ : Tidak terdapat pengaruh antara strategi pengadaan stok terhadap pendapatan perusahaan di SPBU PT. Ma'soem Bandung.

$\mathrm{H}_{1}$ :Terdapat pengaruh antara strategi pengadaan stok terhadap pendapatan perusahaan di SPBU PT. Ma'soem Bandung.

Berdasarkan hasil perhitungan dengan uji $\mathrm{t}$ diperoleh $\mathrm{t}$ hitung sebesar 4,1650. Dengan taraf signifikan 0,025 (0,05:2) dan dengan $\mathrm{db}=28$ diperoleh nilai $\mathrm{t}$ tabel sebesar 2,048. Dari hasil perhitungan maka diketahui bahwa $\mathrm{t}$ hitung $=4,1650>\mathrm{t}$ tabel $=2,048$, maka $\mathrm{H}_{0}$ ditolak. Dengan demikian $\mathrm{H}_{1}$ diterima, dan kesimpulannya adalah terdapat pengaruh yang signifikan antara strategi pengadaan stok terhadap pendapatan perusahaan di SPBU PT. Ma'soem Bandung.

\section{(2). Uji Signifikansi Simultan ( Uji F )}

Ujisignifikansi antaravariabel harga BBM Pertamina $\left(\mathrm{X}_{1}\right)$ dan variabel strategi pengadaan stok $\left(\mathrm{X}_{2}\right)$ dengan variabel pendapatan perusahaan (Y). Hipotesis penelitian yang akan di uji dirumuskan sebagai berikut :

$\mathrm{H}_{0}$ : Tidak terdapat pengaruh antara harga BBM Pertamina dan strategi pengadaan stok

terhadap pendapatan perusahaan di SPBU PT. Ma'soem Bandung.

$\mathrm{H}_{1}$ : Terdapat pengaruh antara harga BBM Petamina dan strategi pengadaan stok terhadap pendapatan perusahaan di SPBU PT. Ma'soem Bandung.

Berdasarkan hasil perhitungan dengan uji $\mathrm{F}$ diperoleh $\mathrm{F}$ hitung sebesar 11,2262. Dengan taraf signifikan $(\alpha)$ $=5 \% \mathrm{dk}=27$ diperoleh $\mathrm{F}$ table sebesar 3,35. Dari hasil perhitungan diketahui bahwa $\mathrm{F}$ hitung $=11,2262>\mathrm{F}$ tabel $=$ 3,35 maka $\mathrm{H}_{0}$ ditolak. Dengan demikian dapat disimpulkan bahwa terdapat pengaruh yang signifikan secara simultan antara harga bahan bakar minyak Pertamina dan strategi pengadaan stok terhadap pendapatan perusahaan di SPBU PT. Ma'soem Bandung.

Berdasarkanhasil analisis diperoleh temuan penelitian sebagai berikut :

a. Pengaruh harga BBM Pertamina terhadap pendapatan perusahaan 
Pengujian kuatnya pengaruh variabel harga BBM Pertamina $\left(X_{1}\right)$ terhadap pendapatan perusahaan (Y), menghasilkan koefisien korelasi sebesar 0,4335. Koefisien sebesar 0,4335 menunjukkan pada tingkatan korelasi dan kekuatan pengaruh yang cukup dan memiliki pengaruh yang positif karena nilai yang dihasilkan positif.

Kontribusi yang diberikan oleh perubahan harga BBM Pertamina $\left(\mathrm{X}_{1}\right)$ terhadap pendapatan perusahaan $(\mathrm{Y})$ hanya sebesar $18,79 \%$ dan selebihnya sebesar $81,21 \%$ dipengaruhi oleh faktor lain.

Pengujian hipotesis menyimpulkan bahwa terdapat pengaruh yang signifikan antara harga BBM
Pertamina terhadap pendapatan perusahaan. Hal ini ditunjukkan dari hasil perhitungan uji $t$ sebesar 2,5455 lebih besar dari $t$ tabel dengan tingkat signifikan $0,025 \%$ (dua sisi) dan $\mathrm{db}=28$ adalah 2,048.

Hubungan antara kedua variabel berdasarkan hasil analisis regresi menunjukkan bahwa $\mathrm{Y}=53,2557+$ $0,1849 \mathrm{X}_{1}$ yang artinya setiap peningkatan satu unit skor pada variabel harga Bahan Bakar Minyak Pertamina $\left(\mathrm{X}_{1}\right)$ akan diikuti oleh peningkatan skor pada variabel pendapatan perusahaan (Y) sebesar 53,2557 pada konstanta sebesar $0,1849 \mathrm{X}_{1}$.

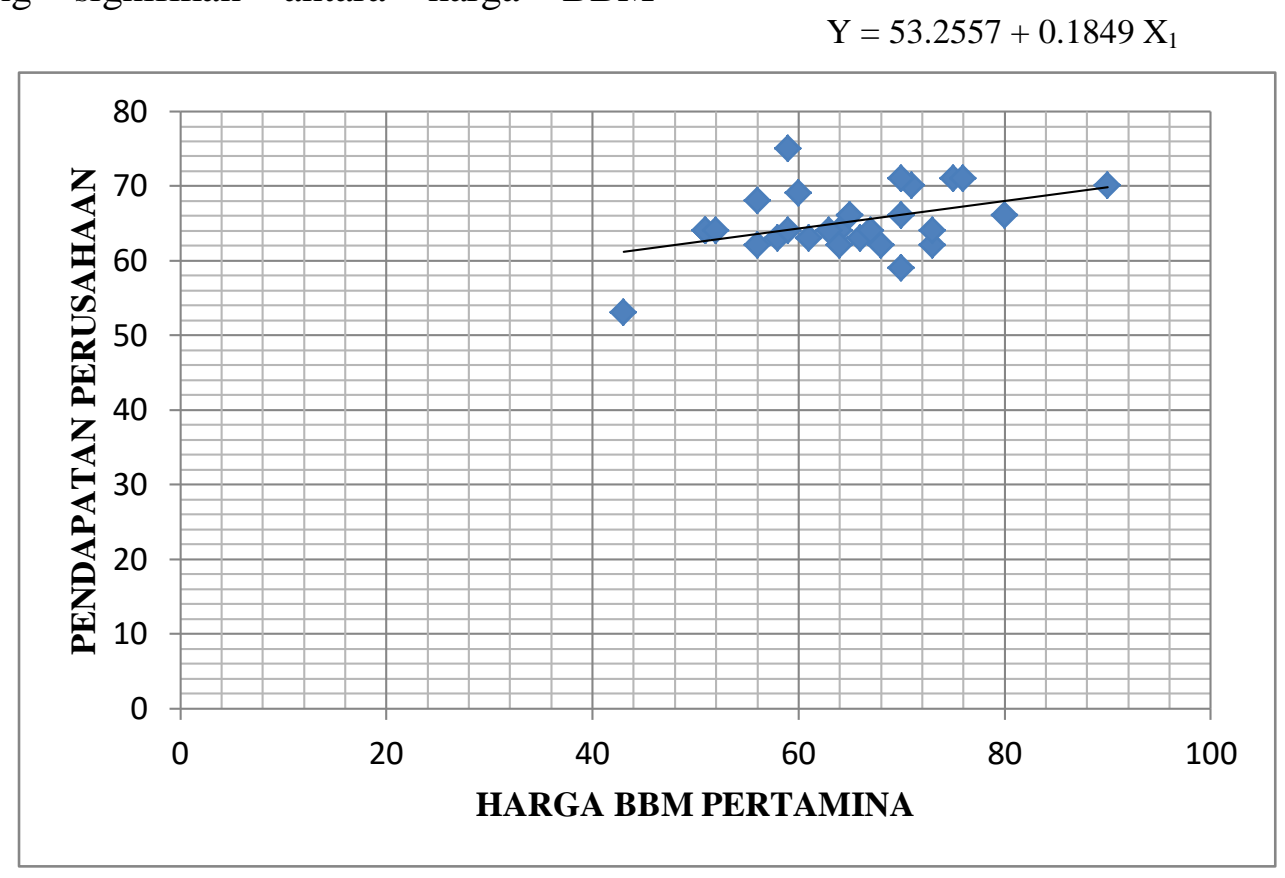

Gambar 3.1.

Hubungan Harga BBM Pertamina dengan Pendapatan Perusahaan

Dari gambar grafik di atas tampak bahwa semakin tinggi harga BBM, maka pendapatan perusahaan cenderung meningkat. Dengan demikian dapat disimpulkan bahwa ada pengaruh yang cukup positif dan signifikan antara harga BBM Pertamina dengan pendapatan perusahaan di SPBU PT. Al Ma'soem Bandung. 


\section{b. Pengaruh strategi pengadaan stok terhadap pendapatan perusahaan}

Pengujian

kuatnya

pengaruhvariabel strategi pengadaan stok $\left(\mathrm{X}_{2}\right)$ terhadap pendapatan perusahaan $(\mathrm{Y})$, menghasilkan koefisien korelasi sebesar 0,6185. Koefisien sebesar 0,6185 menunjukkan pada tingkatan korelasi dan kekuatan pengaruh yang kuat serta memiliki pengaruh yang positif karena nilai yang dihasilkan positif.

Kontribusi yang diberikan oleh strategi pengadaan stok $\left(\mathrm{X}_{2}\right)$ terhadap pendapatan perusahaan $(\mathrm{Y})$ hanya sebesar $38,25 \%$ dan selebihnya sebesar $61,75 \%$ dipengaruhi oleh faktor lain.

Pengujian

hipotesis menyimpulkan bahwa terdapat pengaruh yang signifikan dari strategi pengadaan $\mathrm{Y}=28.3617+0.6236 \mathrm{X}_{2}$ stok terhadap pendapatan perusahaan. Hal ini ditunjukkan dari hasil perhitungan uji $\mathrm{t}$ sebesar 4,1650 lebih besar dari t tabel dengan tingkat signifikan $0,025 \%$ (dua sisi) dan $\mathrm{db}=28$ adalah 2,048.

Hubungan antara kedua variabel berdasarkan hasil analisis regresi menunjukkan bahwa $\mathrm{Y}=28,3617+$ $0,6236 \mathrm{X}_{2}$ yang artinya setiap peningkatan satu unit skor pada variabel strategi pengadaa stok (X2) akan diikuti oleh peningkatan skor pada variabel pendapatan perusahaan (Y) sebesar 28,3617 pada konstanta sebesar $0,6236 \mathrm{X}_{2}$.

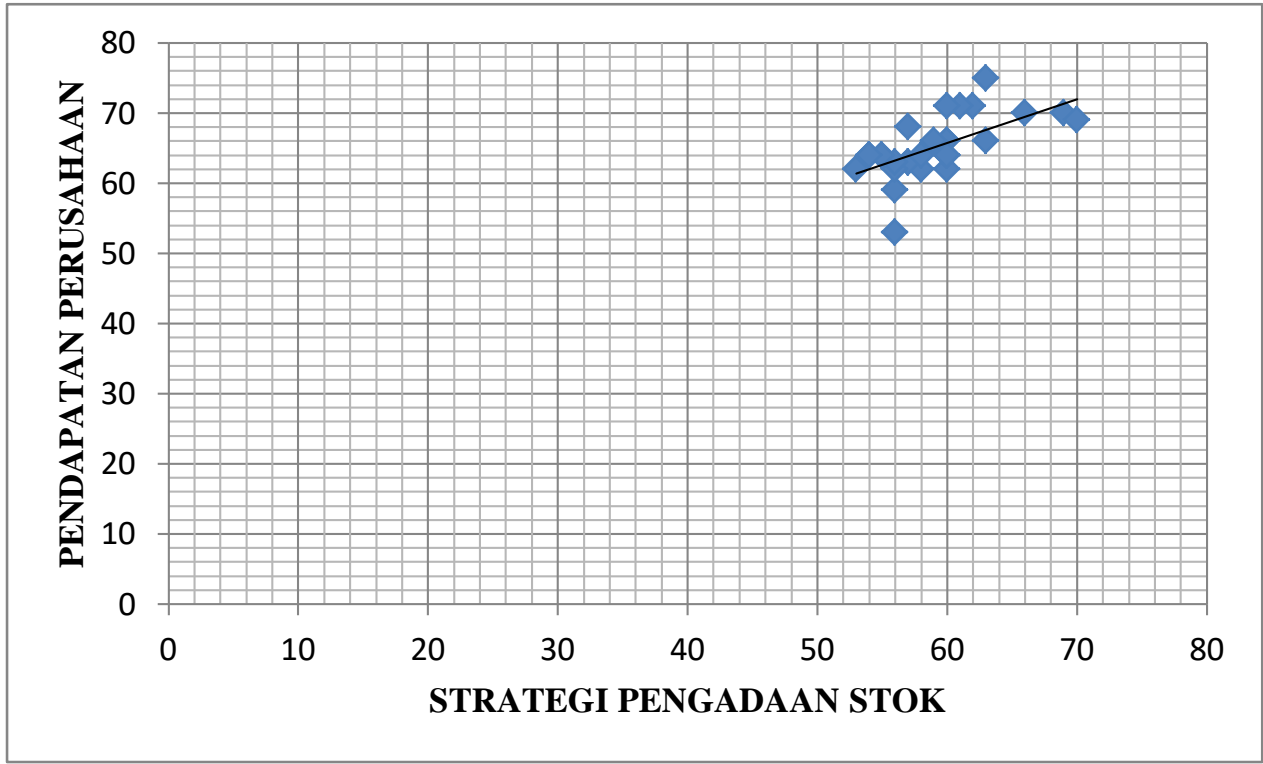

Gambar 3.2.

Hubungan Strategi Pengadaan Stok dengan Pendapatan Perusahaan

demikian dapat disimpulkan

Dari gambar grafik di atas tampak bahwa semakin tinggi strategi pengadaan stok, maka semakin tinggi pula tingkat pendapatan perusahaan. Dengan bahwa terdapat pengaruh yang tergolong kuat dan signifikan antara strategi pengadaan stok dengan pendapatan 
perusahaan di SPBU PT. Al Ma'soem Bandung.

\section{c. Pengaruh harga BBM Pertamina dan strategi pengadaan stok terhadap pendapatan perusahaan}

Pengujian kuatnya pengaruhantara variabel harga BBM Pertamina $\left(\mathrm{X}_{1}\right)$ dan strategi pengadaan stok $\left(\mathrm{X}_{2}\right)$ terhadap pendapatan perusahaan (Y), menghasilkan koefisien korelasi sebesar 0,6738. Koefisien sebesar $\quad 0,6738$ menunjukkan pada tingkatan korelasi dan pengaruh yang kuat dan memiliki pengaruh yang positif karena nilai yang dihasilkan positif.

Kontribusi yang diberikan oleh perubahan harga BBM Pertamina $\left(\mathrm{X}_{1}\right)$ dan strategi pengadaan stok $\left(\mathrm{X}_{2}\right)$ terhadap pendapatan perusahaan (Y) sebesar $45,40 \%$ dan selebihnya sebesar $54,60 \%$ dipengaruhi oleh faktor lain.

Pengujian

hipotesis

menyimpulkan bahwa terdapat pengaruh yang signifikan secara simultan antara harga BBM Pertamina dan strategi pengadaan stok dengan pendapatan perusahaan. Hal ini ditunjukkan dari hasil perhitungan uji $\mathrm{F}$ sebesar 11,2262 lebih besar dari $F$ tabel dengan tingkat signifikan 0,05 dan $\mathrm{dk}=27$ adalah 3,35.

Hubungan antara ketiga variabel berdasarkan hasil analisis regresi menunjukkan bahwa $\mathrm{Y}=25,4761+0,1190 \mathrm{X}_{1}+0,5429 \mathrm{X}_{2}$ hal ini menggambarkan arah hubungan variabel harga BBM Pertamina dan variabel strategi pengadaan stok dengan variabel pendapatan perusahaan adalah searah. Dari persamaan regresi tersebut dapat diinterpretasikan bahwa : 1. Konstanta sebesar 25,4761 artinya jika harga BBM Pertamina $\left(\mathrm{X}_{1}\right)$ dan strategi pengadaan stok $\left(\mathrm{X}_{2}\right)$ nilainya 0 , maka nilai dari pendapatan perusahaan adalah 25,4761. 2. Makna nilai koefisien regresi berganda $\mathrm{X}_{1}$ sebesar 0,1190 menunjukkan bahwa harga BBM Pertamina mempunyai hubungan positif dengan pendapatan perusahaan, dimana semakin tinggi nilai koefisien, maka akan semakin menaikan nilai pendapatan perusahaan.

3. Makna dari koefisien regresi berganda $\mathrm{X}_{2}$ 0,5429 menunjukkan bahwa strategi pengadaan stok juga mempunyai hubungan yang positif dengan pendapatan perusahaan.

Dengan demikian dapat disimpulkan bahwa terdapat pengaruh yang signifikan secara simultan antara harga BBM Pertamina dan strategi pengadaan stok terhadap pendapatan perusahaan di SPBU PT. Ma'soem Bandung.

\section{KESIMPULAN}

Berdasarkan hasil penelitian di lapangan dan pembahasan yang telah diuraikan mengenai pengaruh harga BBM Pertamina dan strategi pengadaan stok terhadap pendapatan perusahaan di SPBU PT. Ma'soem Bandung, maka dapat disimpulkan bahwa

(1) Terdapat pengaruh yang kuat positif dan signifikan antara variabel harga BBM Pertamina $\left(\mathrm{X}_{1}\right)$ terhadap variabel pendapatan perusahaan (Y). Dengan tingkat korelasi yang cukup, dan kontribusi yang diberikan variabel harga BBM Pertamina terhadap pendapatan perusahaan sebesar 18,79\%. Dari hasil analisis regresi menunjukkan bahwa $\mathrm{Y}=$ $53,2557+0,1849 \mathrm{X}$, dimana hubungan kedua variabel tersebut searah dan setiap perubahan pada variabel harga BBM 
Pertamina baik itu perubahan harga naik maupun perubahan harga turun akan mempengaruhi terhadap pendapatan perusahaan di SPBU PT. Al Ma'soem Bandung; (2)Terdapat pengaruh yang kuat positif dan signifikan antara variable strategi pengadaan stok $\left(\mathrm{X}_{2}\right)$ terhadap variabel pendapatan perusahaan (Y). Dengan tingkat korelasi yang kuat, dan kontribusi sebesar 38,25 \% yang diberikan oleh variabel strategi pengadaan stok terhadap variabel pendapatan perusahaan. Dari hasil analisis regresi menunjukkan bahwa $\mathrm{Y}=$ $28,3617+0,6236 \mathrm{X}$ dimana hubungan kedua variabel tersebut searah dan perubahan pada variabel strategi pengadaan stok akan mempengaruhi terhadap variabel pendapatan perusahaan. Hal ini menunjukkan bahwa strategi sebagai pedoman diperlukan dalam pengadaan atau pembelian BBM Pertamina untuk menjaga kelancaran operasi perusahaan dalam memenuhi permintaan konsumen, yang pada akhirnya akan mempengaruhi penerimaan

\section{Daftar Pustaka}

Abdullah, T. dan Tantri, F. 2013. Manajemen Pemasaran. Edisi 1.Cetakan ke-2. Jakarta : RajaGrafindo Alma, B. 2009. Dasar-dasar Bisnis dan Pemasaran.Bandung : Alfabeta.Arikunto, S. 2013. Prosedur Penelitian Suatu Pendekatan Praktis. Jakarta : PT.Rineka Cipta.Bungin, B.2013. Metodologi Penelitian Sosial \& Ekonomi.Format-format

Kuantitatif \& Kualitatif untuk Studi Sosiologi, Kebijakan Publik, perusahaan. (3) Terdapat pengaruh yang kuat positif dan signifikan secara simultan antara variabel harga BBM Pertamina $\left(\mathrm{X}_{1}\right)$ dan strategi pengadaan stok $\left(\mathrm{X}_{2}\right)$ terhadap pendapatan perusahaan (Y) dan memiliki pengaruh yang searah dengan tingkat korelasi yang kuat. Hubungan ketiga variabel tersebut dapat digambarkan oleh persamaan regresi berganda $\mathrm{Y}=25,4761+0,1190 \mathrm{X}_{1}+$ $0,5429 \mathrm{X}_{2}$ yang artinya harga BBM Pertamina dan strategi pengadaan stok secara simultan mempunyai hubungan yang positif dengan pendapatan perusahaan. Perubahan harga BBM Pertamina baik itu harga naik ataupun harga turun akan mempengaruhi terhadap penerimaan pendapatan perusahaan, dan dengan adanya strategi sebagai pedoman untuk mendapatkan persediaan (stok) BBM Pertamina memegang peranan penting dalam pemenuhan kebutuhan konsumen akan bahan bakar, dan pada akhirnya akan mempengaruhi terhadap pendapatan perusahaan.

Komunikasi, Manajemen, dan Pemasaran.Jakarta : Kencana.

Hasan, A. 2013.Marketing dan Kasuskasus Pilihan.Yogyakarta : CAPS.

Herlambang, S. 2014. Basic Marketing (Dasar-dasar Pemasaran). Cara mudahmemahami ilmu pemasaran.Yogyakarta : Gosyen.

Horne \& Wachowicz Jr. 2012. Fundamentals of Financial Management.Dialih bahasa menjadi Prinsip-prinsip Manajemen Keuangan.

Ikatan Akuntan Indonesia. 2002. Standar Akuntansi Keuangan. Jakarta : Salemba Empat. 
Jauch, R. Laurence, dan Glueck, W.F. 1977. Manajemen Strategis dan Kebijakan Perusahaan. (Alih Bahasa : Murad dan AR. Henry Sitanggang). Jakarta : Erlangga.

Kadir. 2015. Statistika Terapan Konsep, Contoh dan Analisis Data dengan ProgramSPSS/Lisrel dalam Penelitian. Edisi kedua.Jakarta : PT. RajaGrafindo Persada.

Kotler, P. dan Keller, L.K. 2009a.Manajemen Pemasaran. Edisi 13 Jilid 1 dan 2.Jakarta : Erlangga.

Margaretha, F. 2011. Manajemen Keuangan untuk Manajer Non Keuangan.Jakarta : Erlangga.

Muhardi dan Aditama, R. 2011.Manajemen Operasi. Suatu Pendekatan Kuantitatif untuk Pengambilan Keputusan.Bandung : Aditama.

Pandiangan, R. 2014. Buku Pintar Akuntansi dan PengendalianUsaha.Yogyakarta : Laksana.
Quadratullah, M.F. 2014. Statistika Terapan Teori, Contoh Kasus, dan Aplikasi dengan SPSS. Yogyakarta : Andi.

Ristono, A. 2009.Manajemen Persediaan. Yogyakarta : Graha Ilmu.

Saladin, Dj. 2001.Manajemen Pemasaran Analisis Perencanaan, Pelaksanaan, dan Pengendalian.Bandung Lindakarya.

Sartono, A. 2011.Manajemen Keuangan. Edisi 3.Yogyakarta : BPFE

Simamora, H. 2002. Akuntansi Basis Pengambilan Keputusan Bisnis.Jakarta : Salemba Empat.

Siregar, S. 2013. Metode Penelitian Kuantitatif Dilengkapi dengan PerbandinganPerhitungan Manual \& SPSS. Jakarta : Kencana.

Sudana, I.M. 2011.Manajemen Keuangan Perusahaan - Teori dan Praktek. Jakarta : Erlangga. 